\title{
THE EFFECTIVENESS OF USING THINK-WRITE-PAIR- SHARE TECHNIQUE IN TEACHING WRITING
}

\author{
Mutia ${ }^{1}$ \\ ${ }^{1}$ IKIP Siliwangi \\ ${ }^{1}$ mutiaaa399@gmail.com
}

\begin{abstract}
The aim of this research is to figure out the use of the think-write-pair-share (TWPS) technique in writing. The method was the quantitative method. The population were tenth-grade students at one of vocational school in Cipanas in the academic year 2020/2021. The sample was 72 students that were divided into control class and experimental class. The experimental class was the class which learn writing recount text through think-write-pair-share (TWPS) technique, while control class was the one which used conventional method. The collected data were analyzed by using T-Test. The result showed that the value of T-test $(0.027)$ was lower $(<)$ than 0,05 . Thus, the alternative hypothesis $(\mathrm{Ha})$ was accepted. This meant that there was the difference between the class taught by think-write-pair-share (TWPS) technique and conventional method. Here, the students learned by using think-write-pair-share (TWPS) tended to be able to share their opinion in recount text. They also became more active. This implies that the think-write-pair-share (TWPS) technique can be used in teaching writing.
\end{abstract}

Keywords: Think-Write-Pair-Share Technique, Writing, Recount Text

\section{INTRODUCTION}

Learning to write in a new language is not always easy (Mundriyah \& Parmawati, 2016). For some people, especially in this Covid-19 pandemic, writing becomes an important skill that people have to master, it makes the communication easier. This statement support by Dantes (2013 cited in Ariyanti, 2016), writing becomes one of the most important aspects of the language skills because the students are helped to expand the other language skills through the teaching of writing skill by the teacher. In Indonesia itself, the government handles the problem in English teaching and learning process through Curriculum 2013 to implement in every level of education.

English is one of the Indonesian subjects in every level of education, especially in Senior High School. English subject covers four basic language skills: reading, speaking, listening, and writing. Nearly all of the students' activities involve writing. Writing is by nature a social process (Dorn \& Soffos, 2001). Writing represents how a message can be communicated to someone. Writing is one of the four language basic skills that in which the students words or symbols for communication. It is one of the people way to communicate with another, in the case of writing, it is from the writer to the reader as their target language.

Students in every level of education need to master their writing ability. Writing skill is different from other language skills, by which it is more flexible and spontaneous. The writer has to write their thought or idea by notice some aspect of writing. The writer has noticed their words to make a sentence while thinking about vocabulary, punctuation, grammar, correctness, etc. In this case, students have to master writing skills to reveal their purpose clearly and directly to the reader. Thus, at the end, the reader can receive and conceive, and also give feedback to the 
students. In fact, writing skill is still hard and students' interest is still low. It is showed by their lack of vocabulary, grammar, and mechanics such as, symbols, and punctuation.

Students' of SMK Negeri 1 Cipanas also had some problems in writing. In general, the problems are lack of vocabulary. They were difficult to decide the grammar or structure. They were also difficult in spelling some words, and mistaken to put the punctuation. Difficulties in writing occurred from internal and external factors. From internal factors, students are not confident and lack of motivation. From external factors, it could be from their teacher (the way of teaching writing or method), the facilities, or teaching instruments.

The English teaching method is changeable. It depends on what students need for their learning process. In this research, the teaching method should be interesting and students-centered. Cooperative learning is one of the teaching methods to lead students work together to share their ideas and thoughts with peers to discuss and to understand something in the learning process. Through this method, students are expected to build their motivation in learning writing. As they can plan, create, discuss, and share their knowledge.

Cooperative learning gives a chance to students' to learn in a group, respect other students' opinions, and increase their critical thinking. In addition, students learn about how to be responsible with their own opinion even though they work together. Through cooperative learning activity, students can directly engage with the lesson, their friends and also their teacher because in cooperative learning activity students can improve their communication skill with make a lot of contact with their members of group and each students in the classroom (Kharisma \& Hidayati, 2018). Although the method is students-centered, it does not mean that the teacher does not participate. In cooperative learning, the teacher has roles as a planner or designer, facilitator and guide and preceptor to make sure the learning process goes well. The traditional Think-Write-Pair-Share strategy is designed to differentiate instruction by providing students with time and structure for thinking about a given topic, enabling them to formulate individual ideas and share these ideas with a peer $(101,2012)$. In other words, think-write-pairshare (TWPS) is a technique or strategy that stimulates and encourages students to think, write down the result of their thoughts, ideas, or opinions, pair and discuss it with other students. At the end, the students have share it in the class.

The use of think-write-pair-share (TWPS) technique is belief to be able to improve students' writing ability. The traditional Think-Write-Pair-Share strategy is designed to differentiate instruction by providing students with time and structure for thinking about a given topic, enabling them to formulate individual ideas and share these ideas with a peer. It supports students to have more time. It is helpful for English as a foreign language learner or non-native. While the students' write their thoughts and ideas, the teacher can walk around the classroom to peek their notes and it can be done to listen students' discussion.

In this research, the think-write-pair-share (TWPS) technique is used in teaching recount text. Recount text retells an experience for telling as well as entertaining the readers (Gerot and Wignell, 1994 cited in Shopiah \& Anggraeni, 2018). Also, recount text retells an event, incident or personal experiences of the writer that point of interest for the reader, such as, a journal, personal diary, letter, history, etc. Recount text has a generic structure consists of orientation, a series of events with sequential sentences, and reorientation that "complete" the sequence of events or conclusion from the whole story (Purnamasari \& Argawati, 2020). 
Based on the explanation above, the aim of this research is to find the effectiveness of thinkwrite-pair-share (TWPS) technique in teaching writing. The hypothesis are:

Ha: $\mu 1<0,05$ (there is significant difference in teaching writing skill through thinkwrite-pair-share technique)

$\mathrm{H}_{0}: \mu 1>0,05$ (there is no significant difference in teaching writing skill through thinkwrite-pair-share technique)

\section{METHOD}

This research used the quantitative method. The quantitative method is a research dealt with numerical, statistical, or mathematical data from phenomena and the relationship. Quantitative method is used to answer questions on relationships within measurable variables to explain, predict, and control a phenomena (Morton, 2018 cited in Lisnawati et al., 2019). This research was conducted at SMK Negeri 1 Cipanas. Population is a group of individuals who have the same characteristic. The small group that is observed called sample (Creswell, 2012 cited in Gustiana et al., 2019). The research population in this research was tenth-grade students and the sample was 72 Teknik Kendaraan Ringan Otomotif tenth-grade students. These students were divided into two classes: control class and experimental class. Control class were the class taught by using conventional method. On the other hand, experimental class was the class taught by using the think-write-pair-share (TWPS) technique. The think-write-pair-share (TWPS) technique were given in three meetings. Regardly the data collection technique, this research used test, especially post-test. The test was given at the end of the treatment, specifically in the third meeting. The data gained were analyzed by using SPSS version 20 . The normality and homogeneity test of the data were calculated. It was continued to the Independent T-test.

\section{RESULTS AND DISCUSSION}

\section{Results}

After conducted the treatment and test, normality test were used to indicate the normality of the data. It used to following criterion:

If sig. $\geq 0.5$, it is estimated that the test data is normally distributed.

If sig. $<0.5$, it is estimated that the test data is not normally distributed.

The conclusion result is shown below.

Table 1. The Normality Test

Tests of Normality

\begin{tabular}{|c|c|c|c|c|c|c|c|}
\hline & \multirow{2}{*}{ Class } & \multicolumn{3}{|c|}{ Kolmogorov-Smirnova } & \multicolumn{3}{|c|}{ Shapiro-Wilk } \\
\hline & & Statistic & Df & Sig. & Statistic & Df & Sig. \\
\hline \multirow{2}{*}{ Score } & Ctrl & ,168 & 36 & ,012 & ,946 & 36 & ,080 \\
\hline & Exp & , 157 & 36 & ,025 & ,946 & 36 & 081 \\
\hline
\end{tabular}

From the table of Shapiro-Wilk, it can be known that significance (Sig.) value of the control class was 0,080 and significance (Sig.) value of the experimental class was 0,081. Because the 
significance (Sig.) value of the control and experimental class is higher (>) than 0,05 , it means data was normally distributed.

After knowing the normality of the data, homogeneity test was used. The aim was to indicate the samples came from the population with the same variants or homogenous. It used the following criterion:

If sig. $\geq 0.5$, it is estimated that the test data is comes from a population with same variants.

If sig. $<0.5$, it is estimated that the test data is comes from a population with different variants.

The result is shown below.

Table 2. Table of Homogeneity

Test of Homogeneity of Variance

\begin{tabular}{|l|r|r|r|r|}
\hline & Levene Statistic & df1 & \multicolumn{1}{c|}{ df2 } & \multicolumn{1}{c|}{ Sig. } \\
\hline \multirow{2}{*}{ Score } &, 000 & 1 & 70 &, 995 \\
Based on Mean &, 010 & 1 & 70 &, 919 \\
Based on Median &, 010 & 1 & 69,827 &, 919 \\
adjusted df &, 000 & 1 & 70 &, 990 \\
\hline
\end{tabular}

From the table above, the significance (Sig.) value Based on Mean was 0,995. Because the significance (Sig.) value of the data was higher ( $>$ ) than 0,05 , it can be known that the data came from a population with the same variants or homogenous.

After knowing the normality and homogeneity test, the T-test was used to know there is significant difference in teaching students writing skills through the think-write-pair-share technique or not between the control and experimental classes. The hypothesis: $\mathrm{H}_{0}: \mu 1>0,05$ (there is no significant differences in teaching writing skill through think-write-pair-share technique)

The basics of decision making in T-test are:

If the Sig (2-tailed) $>0,05$, so the hypothesis $\left(\mathrm{H}_{0}\right)$ is accepted.

If the Sig (2-tailed) $<0,05$, so the hypothesis $\left(\mathrm{H}_{0}\right)$ is rejected.

Independent Samples Test

\begin{tabular}{|c|c|c|c|c|c|c|c|}
\hline & $\begin{array}{c}\text { Levene's Test } \\
\text { for Equality of } \\
\text { Variances }\end{array}$ & \multicolumn{6}{|c|}{ t-test for Equality of Means } \\
\hline F & Sig. & T & Df & $\begin{array}{c}\text { Sig. (2- } \\
\text { tailed) }\end{array}$ & Mean & Std. Error & $\begin{array}{c}95 \% \text { Confidence } \\
\text { Interval of the } \\
\text { Difference }\end{array}$ \\
\hline
\end{tabular}




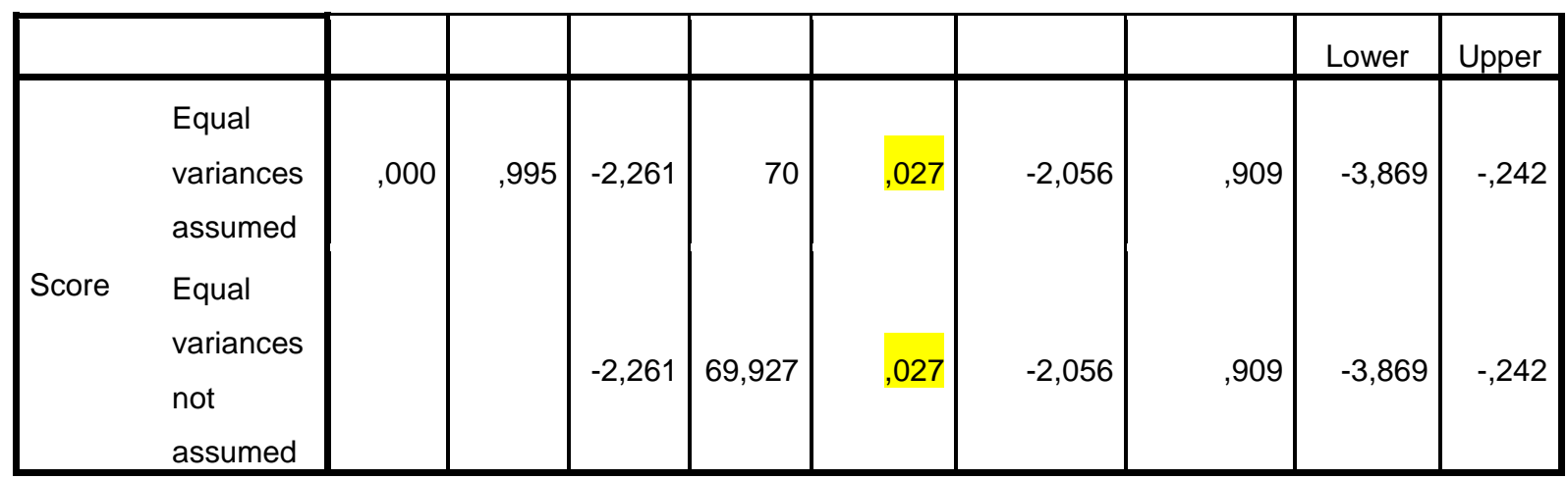

Table 3. Independent Sample Test

Based on Table 3, the value (t) of the T-test was $-2,261$ and the degree of freedom (Df) was 70, the significance (Sig.) value of (2-tailed) was 0,027. It is lower $(<)$ than 0,05 . Thus, it can be concluded that there is a difference between class control that used the conventional method and experimental class that used the think-write-pair-share (TWPS) technique.The result of this research was in accordance with previous research that showed the effectiveness of think-writepair-share technique.

\section{Discussion}

Both high and low efficacy students experienced significant improvement in writing after learning using the think-write-pair-share (TWPS) strategy or technique. Meanwhile, in another analysis using the Independent Sample T-test, the high and low self-efficacy students of the think-write-pair-share (TWPS) technique group got better achievement compared to those in Peer-editing. The analysis using ANOVA test revealed the interactional effect between teaching strategies and self-efficacy toward writing achievement of students with high self-efficacy. While the students with low self-efficacy were greatly influenced by the strategies. Shortly, both teaching strategies are effective to improve students' writing achievement although thinkwrite-pair-share (TWPS) technique is better than peer-editing strategy (Banu, 2016). This previous research result showed that the think-write-pair-share is effective. The advantages of using think-write-pair-share (TWPS) technique are: 1) help students to work in pair; 2) giving the students more time to think and write down their ideas or opinions; 3 ) help the student to increase their thinking ability that affects students' activity in the class.

\section{CONCLUSION}

Based on the result conducted in the research, teaching writing using the Think-Write-PairShare (TWPS) technique that there is difference between the control class and the experimental class. It can be seen from the T-test result. The Significance (Sig.) value of (2-tailed) was 0,027. It is lower $(<)$ than 0,05 . It can be concluded that the hypothesis alternatives (Ha) was accepted. The think-write-pair-share (TWPS) was different. It was more effective to use in teaching writing.

\section{ACKNOWLEDGMENTS}

Alhamdulillahirabbil'alamiin, praise for Allah SWT for all the blessing and grace to enable the researcher to complete this journal entitled the effectiveness of using think-write-pair-share (TWPS) technique in teaching writing at SMK Negeri 1 Cipanas. The researcher also would 
like to say thank you for a lot of help to the researcher's journal supervisor and lecturer. Also for IKIP Siliwangi which gave the researcher the opportunity to publish this journal. And thank you for a lot of help, advice, and motivation from many people.

\section{REFERENCES}

Ariyanti, A. (2016). The Teaching of EFL Writing in Indonesia. Dinamika Ilmu, 16(2), 263. https://doi.org/10.21093/di.v16i2.274

Banu, T. B. J. (2016). The Effectiveness of Collaborative Think-Write-Pair-Share Compared to Peer-Editing Strategy for Teaching Descriptive Text Writing To Students Of High And Low Self-Efficacy (Doctoral dissertation, Universitas Negeri Semarang).

Dorn, L. J., \& Soffos, C. (2001). Scaffolding young writers: A writer's workshop approach. Stenhouse Publishers.

Gustiana, D. S., Poetra, E. P., \& Santoso, I. (2019). Improving The Students 'Writing Narrative Text By Applying Cooperative Learning Type Student Teams Achievement Divisions ( STAD ). $2(4)$,

588-593. https://journal.ikipsiliwangi.ac.id/index.php/project/article/view/3088

Kharisma, I., \& Hidayati, L. A. (2018). Students' Perception in Learning English Using Cooperative Learning Activity. PROJECT (Professional Journal of English Education), 1(3), 207. https://doi.org/10.22460/project.v1i3.p207-216

Lisnawati, D., Elvirasari, D., \& Santoso, I. (2019). Improving Students' Writing Ability Through Think Talk Write Method. Professional Journal of English Education, 2, 2. https://journal.ikipsiliwangi.ac.id/index.php/project/article/view/2660/pdf

Mundriyah, M., \& Parmawati, A. (2016). Using Think-Pair-Share (TPS) to Improve Students'writing Creativity (A Classroom Action Research in the Second Semester Students of STKIP Siliwangi Bandung). Jurnal Ilmiah P2m Stkip Siliwangi, 3(2), 84-91.

Purnamasari, A., \& Argawati, N. O. (2020). the Use Discovery Learning Method in Teaching Writing Recount Text To the Tenth Grade of Sman Ngamprah. PROJECT (Professional Journal of English Education), 3(4), 470. https://doi.org/10.22460/project.v3i4.p470-476

Shopiah, S., \& Anggraeni, R. (2018). Teaching Recount Text Through Scrabble Game. Project Journal, 01, 2. https://journal.ikipsiliwangi.ac.id/index.php/project/article/view/959/pdf 